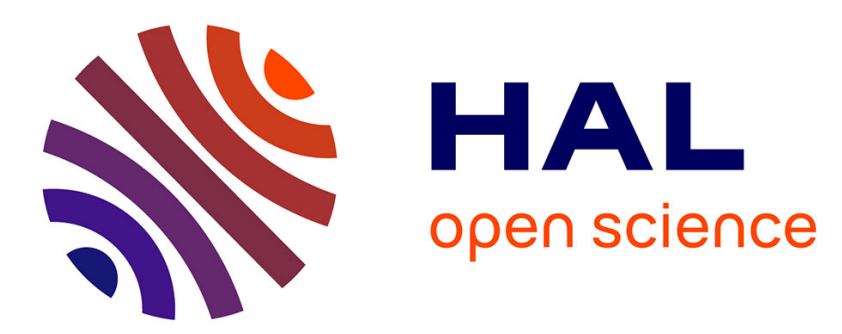

\title{
The maturity of supply chain sustainability disclosure from a continuous improvement perspective
}

\author{
Uche Okongwu, Risako Morimoto, Matthieu Lauras
}

\section{To cite this version:}

Uche Okongwu, Risako Morimoto, Matthieu Lauras. The maturity of supply chain sustainability disclosure from a continuous improvement perspective. International Journal of Productivity and Performance Management, 2013, 62 (8), pp.827 - 855. 10.1108/IJPPM-02-2013-0032 . hal-01758039

\section{HAL Id: hal-01758039 \\ https://hal.science/hal-01758039}

Submitted on 6 Nov 2018

HAL is a multi-disciplinary open access archive for the deposit and dissemination of scientific research documents, whether they are published or not. The documents may come from teaching and research institutions in France or abroad, or from public or private research centers.
L'archive ouverte pluridisciplinaire HAL, est destinée au dépôt et à la diffusion de documents scientifiques de niveau recherche, publiés ou non, émanant des établissements d'enseignement et de recherche français ou étrangers, des laboratoires publics ou privés. 


\title{
The maturity of supply chain sustainability disclosure from a continuous improvement perspective
}

\author{
Uche Okongwu \\ Toulouse Business School, University of Toulouse, Toulouse, France \\ Risako Morimoto \\ SOAS, University of London, London, UK, and \\ Matthieu Lauras \\ Toulouse Business School, Université Toulouse, Mines Albi, France
}

\begin{abstract}
Purpose-From a continuous improvement perspective, the purpose of this paper is to investigate the levels of maturity attained by organisations in reporting their supply chain (as well as non-supply chain) sustainability initiatives. It also investigates the extent to which supply chain sustainability (SCS) disclosure varies between different business sectors, as well as the degree of interconnection between various sustainability criteria. Subsequently, it proposes an improvement framework for reporting and implementing sustainability initiatives across the supply chain.

Design/methodology/approach - To carry out this investigation, corporate sustainability reports of selected companies in ten different industries are downloaded and assessed. The paper uses content analysis and principal component analysis to study the disclosure maturity levels of the different industrial sectors.

Findings - The paper's results show that the disclosure maturity level is higher in business-toconsumer industries than in business-to-business industries on both the social and environmental dimensions. The paper also shows that the highly polluting energy sector is the least advanced in disclosing SCS initiatives. Generally speaking, there is no clear pattern in the way organisations disclose sustainability information. The conclusion is that sustainability disclosure is not yet homogeneously structured across different business sectors and organisations are yet to attain the "adult" maturity age.

Originality/value - Very few researchers can claim to have investigated the maturity levels of SCS disclosure from a continuous improvement perspective. This is probably due to the absence of a universally accepted framework that clearly defines the scope of sustainability. The paper tries to fill this gap by proposing a framework that would not only help researchers to study SCS and stakeholders to read sustainability reports, but would also enable practitioners to improve the quality and reliability of the data disclosed, especially as they apply to the supply chain.
\end{abstract}

Keywords Sustainability, Disclosure maturity levels, Principal component analysis,

Supply chain sustainability, Sustainability criteria, Business-to-customer, Business-to-business

\section{Introduction}

Supply chains are facing growing risks due to greater complexity of products and services, fluctuating energy prices and volatile financial markets. Their strategic goals are set to reduce costs, improve customer services, increase reliability and efficiency of operations and fast delivery of products to markets. Today, companies are increasingly sourcing products from developing countries as supply chains have become more globalised. They are under growing pressure from non-governmental organisations 
(NGOs), states, regulatory bodies, consumers and some investors, to demonstrate that their products are manufactured under acceptable social and environmental standards. According to the United Nations Global Compact (UN Global Compact, 2013), reporting can be a tool to stimulate and enhance sustainability and transparency in the supply chain. Sustainability disclosure can also help to demonstrate to both internal and external stakeholders that good governance, as well as environmental and social issues are taken into consideration in the management of the supply chain. Companies may use sustainability disclosure not only to affirm their legitimacy (Michelon, 2011), but also as a way to manage their reputation risk (Bebbington et al., 2008). Snir (2001) argues that reporting on risk reduction could help to increase brand integrity. According to ACCA (2011), disclosures on supply chain activities would assist customers in making more informed decisions on their purchases and the environmental and social impacts of their use. According to Accenture (2012), large global companies are increasingly encouraging their suppliers to report more climate change-related information and take greater action to reduce their emissions. This would result in greater reductions in greenhouse-gas emissions and greater monetary gains across the entire supply chain.

However, despite the tremendously increasing number of sustainability disclosure by organisations, Hubbard (2011) observed that the quality of sustainability reporting is shortcoming in the sense that the information reported is often not related to material issues. He therefore concluded that the quality of disclosure must be improved in order to provide useful information to users. Pojasek (2012) notes that, given the enormous diversity in the nature of national cultures, business sectors, firms (including their supply chains, products and services) and independent auditing bodies, it would be extremely difficult to standardise the contents and formats of sustainability reporting. It follows that what matters most is to provide organisation with an improvement framework that would enable them to continuously improve the quality of their disclosure no matter the framework used in disclosing their sustainability data.

Using content analysis (CA) and principal component analysis (PCA) techniques, this paper therefore aims to study the maturity levels in sustainability disclosure and thereafter propose a framework for improvement. The proposed framework would: help researchers to study sustainability disclosure; enable firms to assess and improve their maturity in disclosing supply chains sustainability data in order to develop and implement an improvement plan that would enhance their supply chain performance; incite stakeholders to ask for appropriate and reliable information to be included in the report. The paper will start by defining the key terms such as corporate sustainability, supply chain sustainable, voluntary disclosure and maturity model. Through a thorough literature review, the research framework and questions will be presented. Then, in the section on methodology, we will present the disclosure maturity framework, as well as the techniques - CA and PCA - used to analyse the sustainability data compiled from the information downloaded from company web sites. This is followed by the presentation of the CA and PCA results, as well as a discussion of our findings. Finally, we will propose a framework for improving supply chain sustainability (SCS) disclosure, before drawing some conclusions.

\section{Literature review: definitions, research framework and research questions}

2.1 Definitions

In different country contexts and fields of study, "sustainability" may have different meanings (Filho, 2000), but in the business management literature, the most widely 
quoted definition is that found in the Brundtland (1987) where it is defined as: "development that meets the need of the present without compromising the ability of future generations to meet their own needs". While authors such as Kiewiet and Vos (2007) consider this to be the definition of "sustainability", others (Wilson, 2003; Presley et al., 2007) refer to it as "sustainable development". In this paper, we will use both terms interchangeably. However, the Brundtland's definition being too general and abstract, we will adopt Pojasek's (2012) operationalised definition, which considers sustainability as "the capability of an organisation to transparently manage its responsibilities for environmental stewardship, social wellbeing, and economic prosperity over the long term while being held accountable to its stakeholders". When sustainable development is incorporated by organisations, it is called corporate sustainability (Baumgartner and Ebner, 2010). Whatever the way this term is defined, it is generally agreed that the performance of a sustainable organisation is based on the "triple-bottom-line" (TBL) approach constituted by the economic, social and environmental components of sustainable development (Elkington, 1997; Hemming et al., 2004; Robins, 2006).

One of the most cited definitions of a supply chain is that given by Christopher (1992), which states that "a supply chain is the network of organizations that are involved, through upstream and downstream linkages, in the different processes and activities that produce value in the form of products and services delivered to the ultimate consumer". Though a sustainable supply chain can be considered logically and intuitively as the application of sustainability to a supply chain, Kleindorfer et al. (2005) extended it by defining sustainable supply chains using the concept of closed-loop supply chains and TBL thinking. The definition of Carter and Rogers (2008) further adds transparent integration of an organisation's social, environmental and economic goals. Given the pressure from different stakeholders, twenty-first century organisations need to incorporate these sustainability goals into the management of their supply chains. Sustainable supply chain management (SSCM), is defined by Seuring and Müller (2008) as "the management of materials, information and capital flows as well as cooperation among companies along the supply chain while integrating goals from all three dimensions of sustainable development, i.e. economic, environmental and social, which are derived from customer and stakeholder requirement". This is the definition adopted in this paper.

Considered as a voluntary disclosure, sustainability reporting is one way for firms to communicate their economic, environmental and social performance. Voluntary disclosures are defined as "disclosures of firm's information in excess of those required by laws, accounting standards or stock exchange listing requirements regulations" (Watson et al., 2002). Sustainability reporting has emerged as an important tool within an overall SCM strategy, and is defined as "the practice of measuring, disclosing, and being accountable for organisational performance while working towards the goal of sustainable development" (GRI, 2010). The Global Reporting Initiative (GRI), initiated the first phase of the Global Action Network for Transparency in the Supply Chain (GANTSCh) Programme in 2009. Since the year 2000, the number of companies producing sustainability reports has been increasing along with the level of disclosure and its diversity (Hys and Hawrysz, 2012). Though there are other reporting frameworks such as Dow Jones, the Accounting for Sustainability Project (A4S), and the Value Creation Framework (Adams and Simnett, 2011). Ballou et al. (2012) reported that 92.4 per cent of the respondents in their study utilised the GRI standard, which is considered to be the most comprehensive. Though the A4S and the GRI have since 
August 2010 come up with a more integrated framework, known as International Integrated Reporting Committee (IIRC) (Ballou et al., 2012), the GRI remains the predominant standard used by firms whose reports are analysed in this paper.

A maturity model is defined as "a structured collection of elements that describe the characteristics of effective processes at different stages of development" (Pullen, 2007). It is therefore designed to incite and enable organisations to achieve higher levels of performance. Capability maturity models have been developed for processes in different disciplines: P-CMM for human resources management (Türetken and Demirörs, 2004), BIMM and TDWI, for business intelligence (Lukman et al., 2011), Hines, BPiPG, SFfC, CII, CCWRM and MP for supply chain relationship management (Meng et al., 2011), CMMI for software engineering (Mani et al., 2010), OPM3 for project management, EFQM and BCPE for quality management (Asif et al., 2011) and SICT-CMF for sustainable information technology (Curry et al., 2012). The maturity model developed in this paper will be adapted from the SICT-CMF (which has been applied to studies on sustainability) and the quality management models (which are oriented towards continuous improvement.

\subsection{Research framework}

Given the diversity of definitions that exist in extant literature and in order to develop a sufficiently comprehensive framework for the work presented in this paper, we need to widen the scope of the different terms defined in Section 2.1. To begin with, corporate sustainability borrows elements from four concepts: sustainable development, corporate responsibility, stakeholder theory and corporate accountability (Wilson, 2003). Wirtenberg et al. (2007) argue that long-term shareholder value can be increased by integrating economic, environmental and social opportunities into firms' business strategies. Dyllick and Hockerts (2002) combined the sustainability and stakeholder concepts to define corporate sustainability as "meeting the needs of a firm's direct and indirect stakeholders without compromising its ability to meet the needs of future stakeholders as well". Kiewiet and Vos (2007) emphasised the issue of performance by stating that "an organisation is considered sustainable if a certain minimum level of performance is attained in the three 'P-areas' (people, planet and profit)". These three Ps - people, planet and profit - correspond, respectively, to the three components of sustainability - social, environmental and economic.

These various components of corporate sustainability embrace the eight elements (strategy, governance, economic, environment, social-employees, social-customers, social-suppliers and social-community) presented in a comprehensive framework developed by CorporateRegister (2008) and cited by Hubbard (2011). Based on this, the disclosure reporting framework that we will use for our study can be seen in Figure 1. This framework is adapted from CorporateRegister's framework, taking into consideration the different perspectives of sustainability discussed above.

SCS requires effective management of environmental, social and economic impacts with good governance practices throughout the lifecycles of goods and services (BSR, 2010). Thus, corporate sustainability reports should contain qualitative and quantitative information on economic, environmental and social effectiveness and efficiency (Schaltegger and Wagner, 2006). Sustainable supply chain governance systems differ from regular supply chains in their focus on environmental and social ethical goals, NGO involvement and third-party compliance control (Vermeulen, 2008). TBL covers all three dimensions of sustainability, which implies moving beyond reporting on only their financial "bottom line" (Elkington, 1994). Companies often 


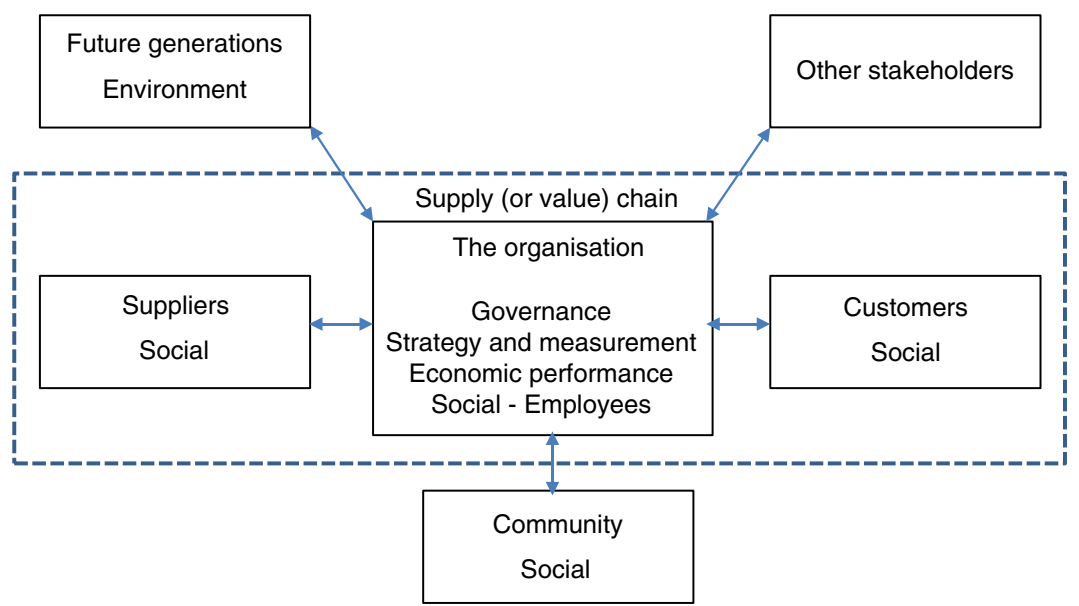

Source: Adapted from CorporateRegister

Figure 1.

Disclosure reporting framework

choose the TBL approach in order to recognise broader societal and environmental objectives (Wiedmann and Lenzen, 2008). The importance of stakeholder management in SSCM is also often cited (Cetinkaya, 2011). Identifying the right stakeholders and their "stake" would enable companies to assess their risks and opportunities. Figure 1 enables us to identify the major criteria that can be used to assess the level of disclosure in the reporting of firms' corporate sustainability initiatives and performance. These criteria are: stakeholders, governance, supply chain, sustainability attributes, TBL performance measures and sustainability standards.

We can define stakeholders as groups or individuals who can affect or are affected by the activities of an organisation (Freeman, 1984) or who have interest in its actions as well as the ability to influence it (Savage et al., 1991). There are different ways of categorising stakeholders but, in this paper, we will adopt the categories defined by Henriques and Sadorsky (1999):

- regulatory stakeholders (governments, trade associations, informal networks, competitors, etc.);

- organisational stakeholders (customers, suppliers, employees, investors and shareholders);

- community stakeholders (community groups, environmental organisations, other political lobbies); and

- media.

Regarding governance, in all sustainable development projects, top management would want to know the extent to which the overall short- and long-term performance of the firm would be impacted. Rocha et al. (2007) note that, in most practical situations, trade-offs between the conflicting objectives (economic, social and environmental) of sustainable development is inevitable and this requires making decisions at the corporate level from the "big picture" perspective. The EFQM model highlights the role of leadership in taking responsibility for a sustainable future (Asif et al., 2011). Therefore, sustainable development goals should be integrated into corporate strategy and policies in order to ensure effective and long-term performance. Though their study was not conclusive, Aras and Crowther (2008) tried to establish a link between 
good governance and sustainability. They stated that the four principles of good corporate governance (transparency, accountability, responsibility and fairness) are related with the firm's corporate social responsibility. We have earlier mentioned that corporate sustainability includes corporate social responsibility. We can therefore deduce that good corporate governance is related with corporate sustainability.

According to De Man and Burns (2006), "a supply chain links production units, one unit's outputs providing inputs into another unit or multiple units". Based on this definition and that of Christopher (1992), one can say that the key components that constitute a supply chain are: the upstream organisations which supply inputs to other upstream organisations or to the focal firm; the resources used by each production unit to transform inputs into outputs; the processes and activities which transform the inputs into outputs; the downstream organisations to which the outputs are shipped, down to the ultimate customer. All these supply chain components are associated with the three dimensions of sustainability. Linton et al. (2007) argue that "sustainability must integrate issues and flows that extend beyond the product design, manufacturing by-products, by-products produced during product use, product life extension, product end-of-life, and recovery processes at end of life". Beamon (2005) considers that environmental conscious supply chain management has historically emphasised on product recovery (recycling, remanufacturing or reuse) or the product design function (e.g. design for environment). Field and Sroufe (2007) studied the implications (for supply chain management) of using recycled materials in manufacturing. Kleindorfer et al. (2005) claim that sustainable operations management combines the profit and efficiency focus of traditional operations management with the company's stakeholder issues, as well as its environmental impacts. The concept even broadens to include green product and process development (Rahimifard and Clegg, 2007; Geldermann et al., 2007), green supply chains and technology (Vachon, 2007), lean and green suppliers (Simpson and Power, 2005), green SCM and performance (Beamon, 1999; Hervani and Helms, 2005; Rao and Holt, 2005; Zhu et al., 2005), as well as remanufacturing and closed-loop supply chains (Krikke et al., 2004). The definition of Facanha and Horvath (2008) includes profitability, resource effectiveness and Brundtland's definition.

From a very broad perspective, Presley et al. (2007) consider that sustainable development provides "a framework for managing the development of communities, nations, regions, and indeed the entire planet to ensure efficient resource use, creation of efficient infrastructures, protection and enhancing the quality of life [...]". This definition includes corporate initiatives (e.g. building a hospital for a community) that are not directly related to the firm's supply chain operations. Gao and Zhang (2006) even went further to state that "sustainability at the corporate level does not limit itself to the economic and social development in the countries in which the corporation operates [...]". On the other hand, Shrivastava (1995) emphasised on "reducing the long-term risks associated with resource depletion, fluctuations of energy costs, product liabilities, and pollution and waste management". In this case, use of resources and energy, pollution and wastes are directly linked to supply chain operations. It follows that corporate sustainability could include philanthropic and goodwill initiatives as well as attributes directly linked to supply chain operations. For the purpose of our study, we will therefore distinguish between two categories of corporate sustainability initiatives: first, non-SCS initiatives, which we will refer to as societal development sustainability (SDS) and second, SCS, which encompasses corporate sustainability initiatives as they apply to the supply chain, as well as the impact of the activities of the supply chain on the different stakeholders, including the society. 
Regarding performance measures, Gopal and Thakkar (2012) argue that despite considerable evidence from the literature on supply chain performance measurement in recent years, there is a large scope for research to address various issues in supply chain performance measurement, such as characteristics of measures and metrics, benchmarking of measures and use of management practices. However, sustainability performance measures are abundantly found in extant literature (Baumgartner and Ebner, 2010; GRI, 2010; Sherman and DiGuilio, 2010), though they are defined using different terms. Some of the key measures are related to emissions, energy use, hazardous wastes and recycling for the environmental dimension; health, safety, training and child labour for the social dimension; economic value generation and distribution for the economic dimension. Also, Bai et al. (2012) developed business and environmental measures for supply chain sourcing. From a theoretical development perspective, Beske (2012) developed a framework, which integrates dynamic management theories into SSCM practices. For promoting sustainable supply chain performance, Kwik et al. (2011) discuss the importance of alternative disposal options on consumer products and product recovery operations. Looking at these performance measures, we observe that the responsibilities of a firm go beyond the wellbeing of its shareholders to include the environmental, economic and social wellbeing of its employees, suppliers, customers, local communities and the society in general (present and future generations). A firm's corporate sustainability report should therefore clearly show how it assesses achievements and measures performance in each of the three areas (economic, social and environmental).

Though the effectiveness of standards (for addressing sustainability issues) is questionable as most companies do not yet align their efforts across the supply chain (BSR, 2007), Castka and Balzarova (2008) noted that the International Organisation for Standardisation (ISO) survey in 2004 confirmed a growing impact of ISO 9001 (for quality management) and ISO 14001 (for environmental management) on the world economy. Based on their analysis using Japanese data, Arimura et al (2009) argue that ISO 14001 promotes green SCM practices. Castka and Balzarova (2008) predict and argue that for strategic, altruistic or coercive reasons, organisations would adopt ISO 26000 guidance standard for addressing social responsibility issues. BSR (2007) listed some of the international standards used to address social and environmental issues in global supply chains: WRAP, FLA, SA8000, CSC9000T, ICTI CARE, ISO 14001, OHSAS 18001 and ISO 26000. Top management should clearly indicate how the chosen standards contribute to supply chain sustainable development.

Table I summarises the different criteria (stakeholders, governance, supply chain, SDS or societal sustainable development attributes, SCS attributes, TBL performance measures and internationally recognised sustainability standards) that should be taken into account when analysing sustainability disclosure.

\subsection{Research questions}

A lot of research has been done on SSCM, but only from a one-dimensional perspective, looking at just one business sector or one of the three pillars of sustainability: social, economic and environmental. For retail industries, Courville (2003) compared supply chains in the coffee industry using indicators, such as fair price, cost of production and ability to meet basic needs. Aiking and De Boer (2004) discuss the diverging interpretations of food sustainability. Myers (2005) observed not only that the UK construction sector is very fragmented, but also that about 40 per cent of the 42 construction companies analysed, reported only financial information. 


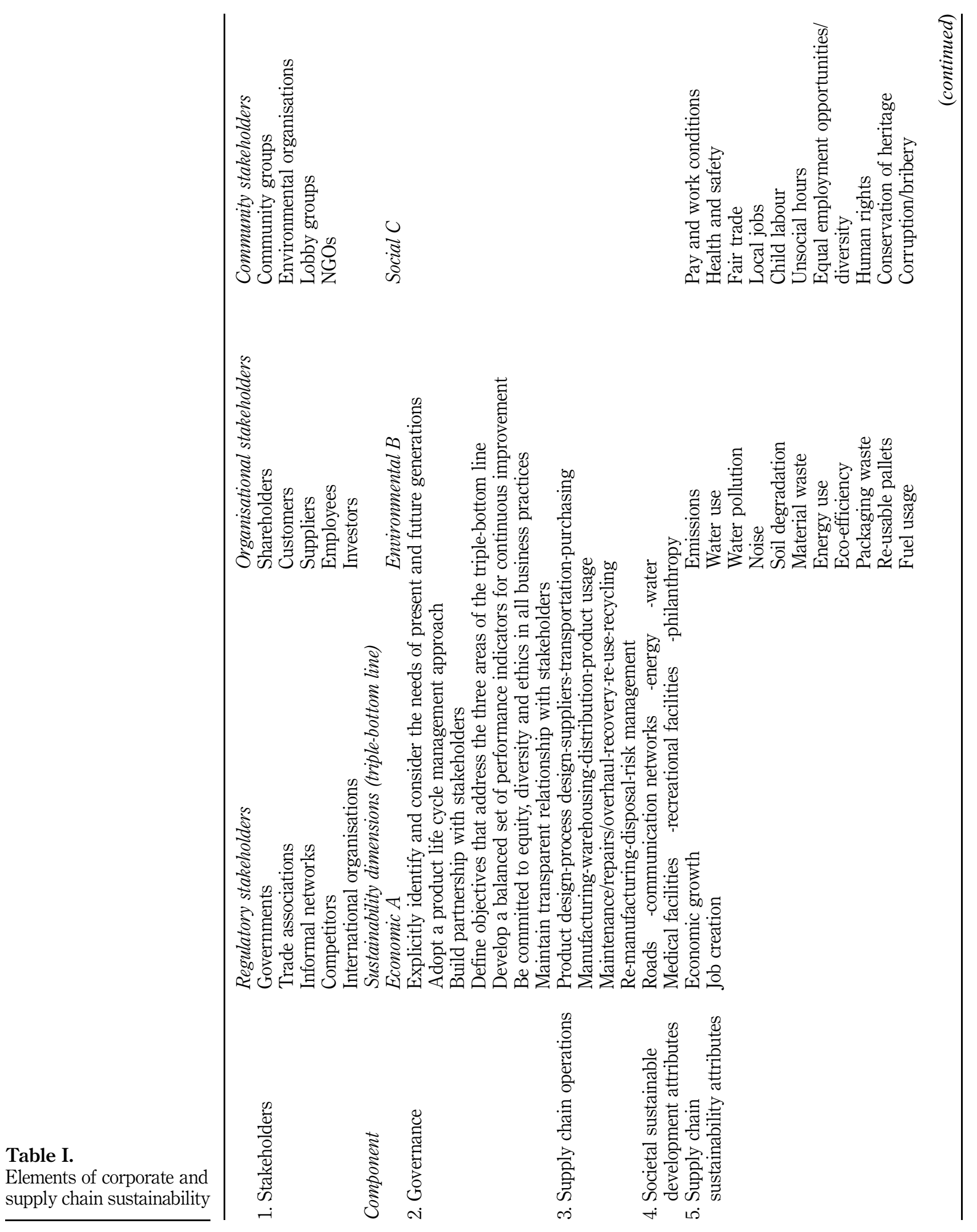




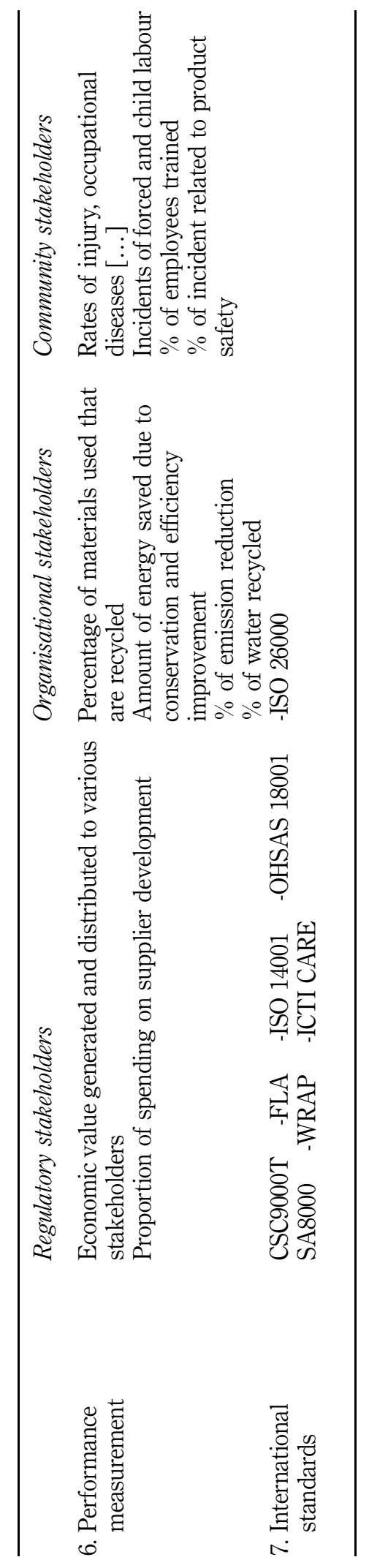

Table I. 
Kang et al. (2010) suggest a sector-specific corporate sustainability management index for the Korean telecommunications industry. Other authors have studied the application of SSCM to manufacturing and electronics-based industries (e.g. Handfield et al., 2005; Vachon and Klassen, 2006). There are many studies on environmental or green supply chain management (Beamon, 1999; Hervani and Helms, 2005; Rao and Holt, 2005; Vachon and Klassen, 2006; Srivastava, 2008; Alexopoulos et al., 2012; Björklund and Forslund, 2013), as well as on social issues (Castka and Balzarova, 2008; Aras et al., 2010; Gori et al., 2012) as they apply to supply chains, but very few adopt a comprehensive approach that takes into consideration all three pillars of sustainability: social, economic and environmental. In other words, many social elements as well as the integration of the three dimensions of sustainability are rarely mentioned (Seuring and Muller 2008; Seuring, 2008).

Sustainability reporting indicates that a company is committed to a process of transparency and stakeholder engagement. Such transparency allows companies to attract a broader range of investors and customers, enhance operational efficiency, improve brand positioning and develop leadership in the marketplace. Yet, a recent research done by Hubbard (2011) revealed that the quality of the information disclosed in these reports is "unsustainable" and must be improved. Therefore, there is still the need to continue searching for ways that would enable organisations to improve their maturity in disclosing sustainability initiatives and performance. Nidumolu et al. (2009) report that vendors consume as much as 80 per cent of the energy, water and other resources used by a supply chain. This notwithstanding, Peukert and Sahr (2010), by analysing companies in the chemical and pharmaceutical industry, observed that "the awareness of potential sustainability opportunities and risks coming up from supply chain management have not yet been sufficiently developed". More emphasis should therefore be laid on SCS. Based on this literature review and discussion, we can formulate three research questions:

$R Q 1$. What maturity levels have firms from different business sectors attained in the continuous improvement process of their sustainability disclosure especially as regards the environmental and social dimensions?

$R Q 2$. In the disclosure of SCS initiatives, to what extent do maturity levels vary between different business sectors?

RQ3. Does the information disclosed by firms show any interconnection between the three dimensions of sustainability as they apply to the supply chain?

By analysing firms' sustainability reports, this paper attempts to empirically answer these questions from a global perspective. Gao and Zhang (2006) note that "it is difficult to distinguish between sustainability reporting from other integrated social and environmental reporting as the latter has moved towards the assessment and reporting on the triple-bottom line performance of an organisation". We will therefore indiscriminately analyse sustainability, corporate sustainability and corporate social responsibility reports.

\section{Methodology}

According to the United Nations Global Compact (UN Global Compact, 2013), SCS management implies management practices that maximise value by managing risks, 
such as supply chain interruptions or delay. Environmental risks can also be passed onto a company through its suppliers (Handfield et al., 2005). Therefore, in this study, key companies in the major industries that are leaders in addressing supply chain risks are selected, in line with the industries identified by KPMG (2008). Most of the companies selected are recognised as sustainability leaders by indices such as FTSE4Good and Dow Jones Sustainability Index. Five representative companies in ten key industries (totalling 50 companies) are selected and their sustainability reports were downloaded from their respective company's web site. Though these reports are publicly available, we have, for ethical reasons, decided to use codes instead of the real company names. Aerospace companies are coded as AERO1 to AERO5, automobile as AUTO1 to AUTO5, chemical as CHEM1 to CHEM5, construction as CONS1 to CONS5, electronics as ELEC1 to ELEC5, energy as ENER1 to ENER5, food as FOOD1 to FOOD5, pharmaceuticals as PHAR1 to PHAR5, retail as RETA1 to RETA5 and telecommunications as TELE1 to TELE5. We observed that there is a very wide variation in the title used by the companies in reporting their sustainability practices. The most commonly used titles are Sustainability (14 out of 50 reports) and Corporate Responsibility (14 out of 50 reports). Some of the other titles are Global Citizenship, Global Reporting Initiative, How We Do Business, Shaping The Future, Creating Shared Value and Viability Performance. This variation in the report titles could be partly due to the lack of consensus in the definition of sustainability, sustainable development and corporate sustainability, as discussed in Sections 2.1 and 2.2.

The first objective of this paper, as expressed in our research question $R Q 1$, is to investigate the maturity level of firms in disclosing their sustainability initiatives and performance. Some authors (Baumgartner and Ebner, 2010; Bask and Kuula, 2011) have conducted general studies on the maturity levels of sustainability disclosure, but since our study aims specifically at providing companies with a framework to continuously improve the disclosure process, we will adopt a continuous improvement approach which is commonly found in the quality management literature. The maturity model in this paper is therefore based on the approach used by the European Foundation for Quality Management (EFQM) for auditing the quality competences and maturity levels of organisations (EFQM, 2013). Applied to sustainability reporting, it simply means that organisations should "measure to manage and manage to change" their disclosure capabilities. Combining this statement with the disclosure assessment criteria presented in Table I, we propose three disclosure maturity levels as shown in Table II, level 1 being the lowest and level 3 the highest.

Level 1 (or the "define" level) aims to check whether the organisation defines and reports, for both SDS and SCS, key stakeholders and their needs, sustainability strategies and policies, and major sustainability attributes that enable to measure performance. At level 2 (or "measure and manage" level), they should report information showing that they measure and manage sustainability issues, a process that should be confirmed by self-assessments and audits. At level 3 (or "improve and change" level), they should report not only how performance measures are used to change and improve performance for the identified stakeholders, but also the engagement of the services of an independent auditing body in order to certify the reliability of the reported information, as well as the continuous improvement process.

The downloaded sustainability reports were analysed qualitatively using the CA approach. CA develops data sets based on the systematic coding of documentary evidence (Hodson, 1999; Holsti, 1969; Jarvenpaa, 1991; Krippendorff, 1980). We basically checked whether the reports contained distinct chapters and/or sub-chapters 


\begin{tabular}{|c|c|c|}
\hline $\begin{array}{l}\text { Level of } \\
\text { disclosure }\end{array}$ & Societal development sustainability & Supply chain sustainability \\
\hline $\begin{array}{l}\text { L3 (Improve and } \\
\text { change) }\end{array}$ & $\begin{array}{l}\text { Based on corporate performance } \\
\text { assessment, an improvement plan is } \\
\text { developed in order to satisfy the major } \\
\text { stakeholders. } \\
\text { Third-party (external) audits are } \\
\text { performed }\end{array}$ & $\begin{array}{l}\text { Based on supply chain performance } \\
\text { assessment, improvement initiatives } \\
\text { are reported throughout closed-loop } \\
\text { supply chains. } \\
\text { Social and environmental factors are } \\
\text { taken into consideration in supplier } \\
\text { development }\end{array}$ \\
\hline $\begin{array}{l}\text { L2 (Measure and } \\
\text { manage) }\end{array}$ & $\begin{array}{l}\text { Corporate performance indicators and } \\
\text { measures are reported. } \\
\text { Self-assessments and audits are } \\
\text { performed }\end{array}$ & $\begin{array}{l}\text { Supply chain performance indicators } \\
\text { and measures are reported. } \\
\text { Sustainability issues are reported as } \\
\text { related to supplier relationship } \\
\text { management }\end{array}$ \\
\hline L1 (Define) & $\begin{array}{l}\text { Stakeholders and their needs are } \\
\text { identified. } \\
\text { Sustainability policies and strategies } \\
\text { are stated. } \\
\text { Key societal development } \\
\text { sustainability attributes are defined }\end{array}$ & $\begin{array}{l}\text { The needs of stakeholders are } \\
\text { identified as they are related to the } \\
\text { supply chains. } \\
\text { Key supply chain sustainability } \\
\text { policies and strategies are defined }\end{array}$ \\
\hline
\end{tabular}

Table II.

Sustainability disclosure maturity levels that address the points included at each of the three disclosure levels, irrespective of the scope of disclosure.

To answer our research questions $R Q 2$ and $R Q 3$, which aim to specifically investigate SCS disclosure, the disclosure reporting framework presented in Figure 1 is further broken down into eight elements that are measured at four levels. Meng et al. (2011) discussed two representations of capability maturity models: stage representation (which assesses an organisation against the existence or absence of defined process areas and produces an overall maturity-level rating) and continuous representation (which assesses all the defined process areas against each maturity level). The SICT-CMF framework (mentioned in Section 2.1) is a continuous representation and our SCS disclosure framework (presented in Table III) is based on this framework. There are four levels of maturity and eight criteria which constitute the process areas.

Two criteria - use of standards and performance measurement are associated to Governance since it is the role of top management to define the system and standards used to monitor and control performance. The environmental dimension looks at the extent to which environmental issues are taken into consideration across the closedloop supply chain, with particular emphasis on pollution, which is considered to be one of the major hazardous externalities of industrial activities (Cormier et al., 2004; Jose and Lee, 2007; Darnall et al., 2008). The different aspects of social sustainability are grouped into two categories: external for relationship with suppliers, customers and the society, and internal for employees. The economic dimension looks on the one hand at how much economic value is generated, and on the other hand at how the generated economic value is shared with the various stakeholders. Economic value distribution management is an allocation of any rents earned by the firm (Lieberman and Balasubramanian, 2005).

As shown in Table III, the four levels of maturity M1, M2, M3 and M4 are labelled, respectively, as "Initial", "Intermediate", "Advanced" and "World class". This table is 


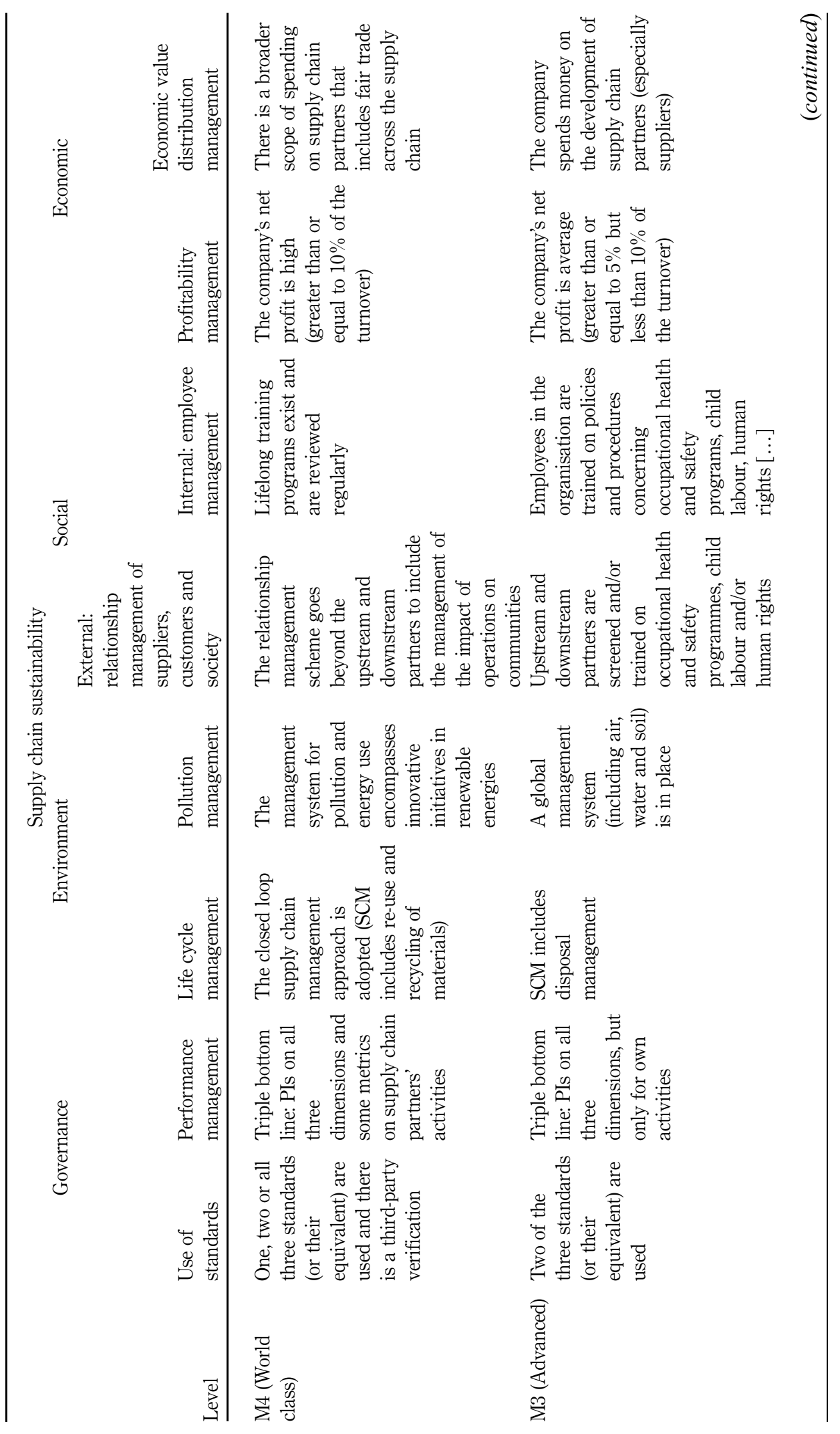

Table III.

Maturity model for supply chain sustainability disclosure 


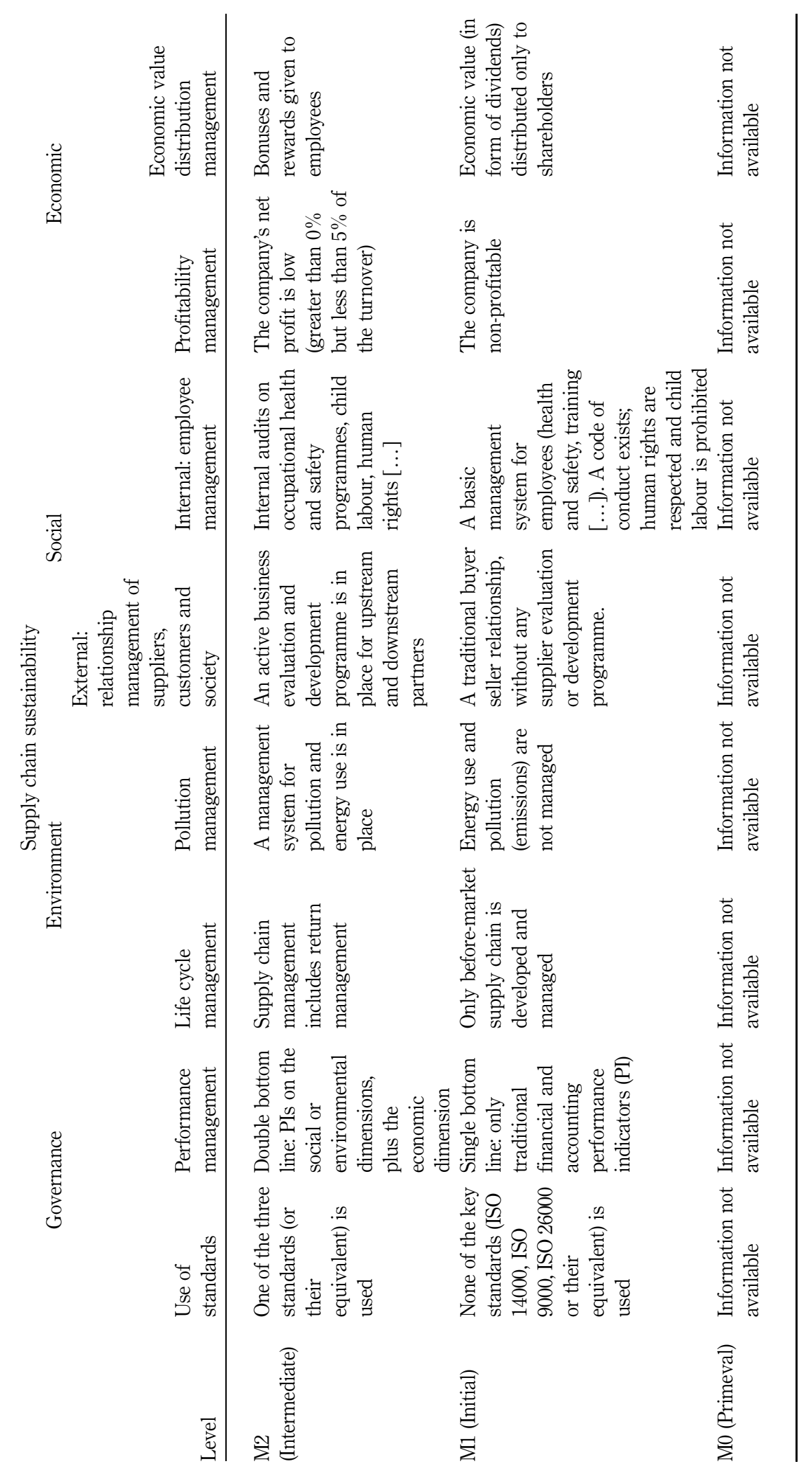


used to score the 50 selected companies, with "initial" corresponding to the lowest level while "world class" corresponds to the highest level. Each of the eight elements is scored using a scale of 1-4, 1 for initial, 2 for intermediate, 3 for advanced and 4 for world class. A score of zero (level M0) means that the information is not reported. As indicated by Meng et al. (2011), it is admitted that some higher level process areas might be partially achieved in an overall lower level of maturity. For example, the closed-loop supply chain management approach might be adopted (level 4 of the "Life cycle management" process area) while the organisation does not use any standard (level 1 of the "use of standards" process area). The results of the scoring are too detailed and voluminous to be included in this paper. However, they will be reflected in the results of the PCA that was performed using the "Le Sphinx" software. Readers interested in the PCA tool are referred to Bryman and Hardy (2003).

\section{Findings and discussion}

4.1 Sustainable maturity levels attained by companies in different business sectors

The results of the CA, done with respect to research question $R Q 1$, are shown in

Figure 2. Organisations at the bottom-left corner of this figure have the lowest level

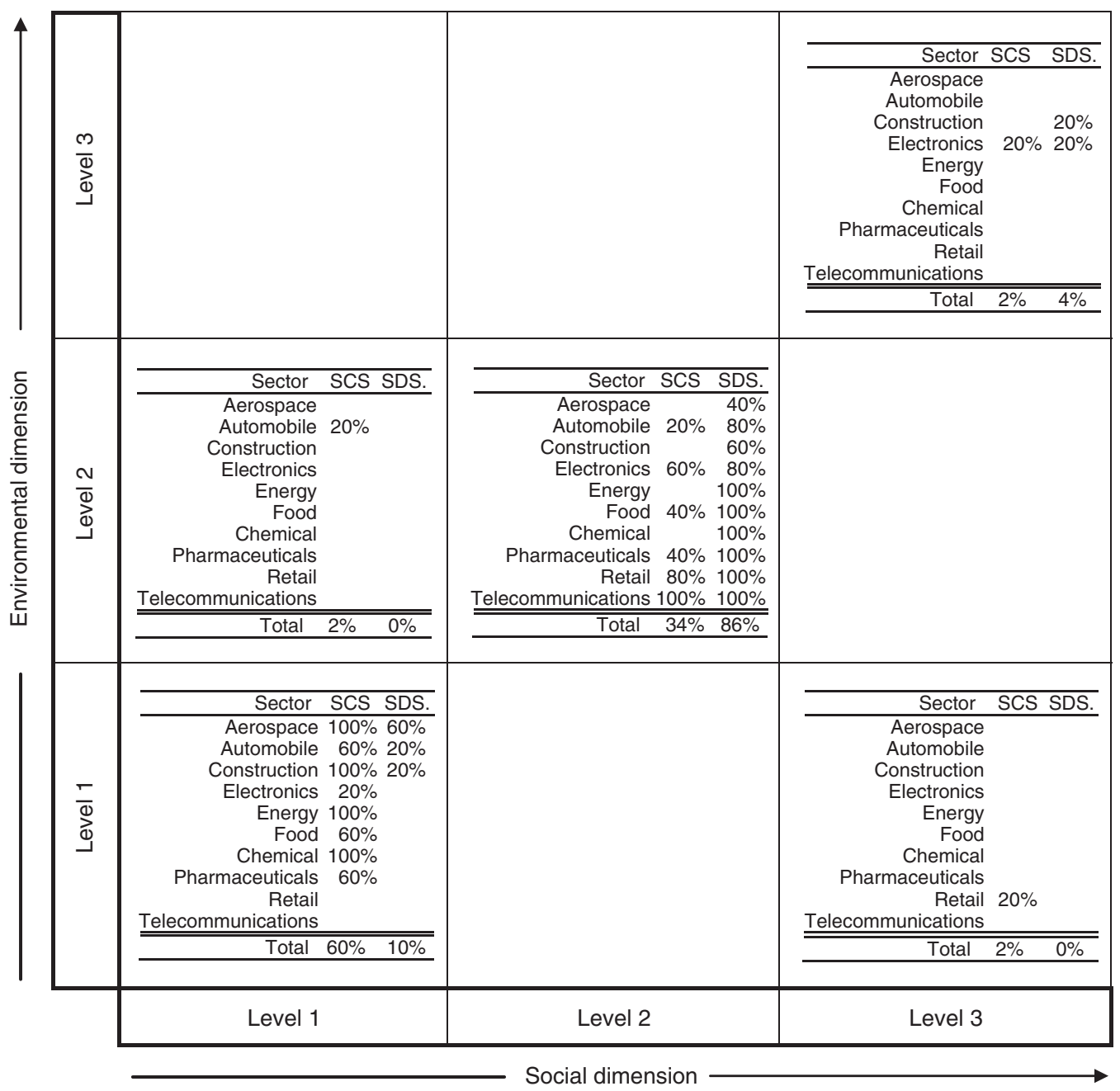

Figure 2.

Content analysis results: disclosure maturity of different industrial sectors 
of maturity in the disclosure of both environmental and social information while organisations in the top-right corner are the most matured. A score of 20 per cent signifies that only one company, out of the five selected in each sector, satisfy the criteria at a given maturity level while 100 per cent means that all the five companies satisfy the criteria. It can be seen in Figure 2 that only one electronic company has the highest maturity level on both axes (environmental and social) and in both areas of sustainability: SCS and SDS. There is also one construction company at this level of maturity but only with respect to SDS.

All the reports mention sustainability elements as they apply to the supply chain, but some (46 per cent of the selected companies) produce separate chapters or even separate reports for their supply chains. Generally, we observed that reports with a separate chapter on the supply chain have a higher level of disclosure of SCS than those without. For example, the only (electronic) company that is at level 3 on both social and environmental dimensions, not only has a separate chapter on supply chain management, but also includes supply chain responsibility as one of its corporate priorities as can be seen in its chairman's opening statement: "Our three global citizenship priorities - supply chain responsibility, climate and energy, and product reuse and recycling - are more critical than ever to our business success".

Based on the results shown in Figure 2, the industries studied are clustered into two groups according to the nature of demand as shown in Figure 3. One of the groups is the business-to-business (B2B) industries and the other is the business-to-consumer (B2C). B2B is a commonly used term for commerce transactions between businesses while $\mathrm{B} 2 \mathrm{C}$ is a term for business activities serving end consumers with products and/or services. In our sample, the B2B industries are aerospace, chemical, construction and energy, and the $\mathrm{B} 2 \mathrm{C}$ industries are food, electronics, pharmaceutical, retail and telecommunications.

In Figure 3, we observe that SCS disclosure maturity of the B2B industries is ranked at level 1 on both the social and environmental dimensions, while it is ranked at level 2 for the B2C industries. We argue that since the B2C companies have more commitments to the downstream supply chain (in the sense that they are closer to the final consumer) they tend to disclose more on the sustainability initiatives and performance of their supply chains. Second, B2C companies tend to consider the

Figure 3.

Company sustainability clusters according to the nature of demand

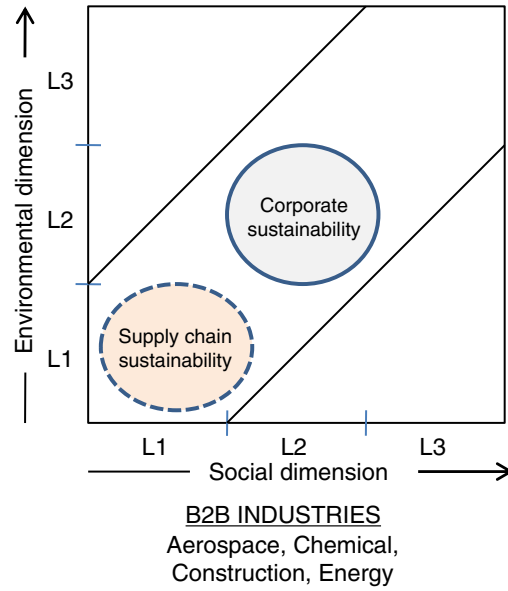

Note: Based on our results

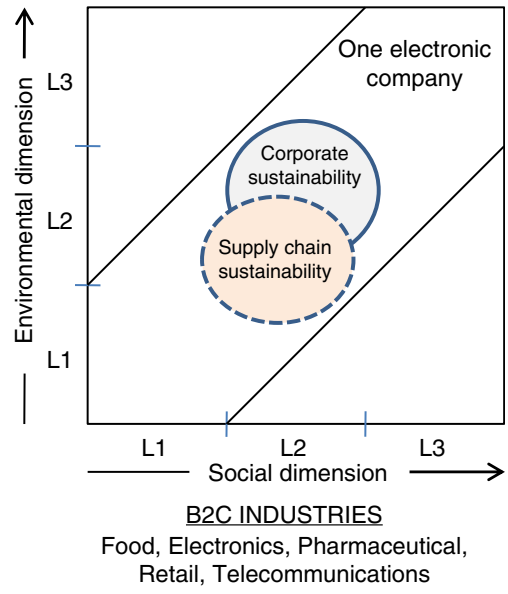

Retail, Telecommunications 
importance of responding to growing customer demands as expressed in the words of the chairman of the most matured electronic company, who states that "These (supply chain responsibilities) are the areas that reflect growing customer demands and where we can make the greatest contribution". Moreover, 60-80 per cent of these B2C companies produce a separate chapter or report on their supply chain, compared to 0-20 per cent of the $\mathrm{B} 2 \mathrm{~B}$ companies. On the contrary, $\mathrm{B} 2 \mathrm{~B}$ companies have more operational activities in the upstream part of the supply chain and tend to disclose less on the downstream SCS. However, some of them disclose issues related to the management of their suppliers. We deduce that the biggest pressure for organisations to report SCS initiatives comes from the customer. To the best of our knowledge, this is the first study that reports a difference in the reporting behaviour of $\mathrm{B} 2 \mathrm{C}$ and B2B companies.

We also note that for the SDS reporting, the two groups are positioned at level 2 on both social and environmental dimensions. This is understandable given the enormous pressures from different stakeholders such as international organisations (United Nations, World Trade Organisation [...] ), NGO, state governments, media and some investors. It can be inferred from this that organisations tend to "buy" the public's loyalty by investing on community development philanthropic projects, especially given that these projects are more visible and easier to measure than supply chain sustainable initiatives. One can logically draw the conclusion that sustainability disclosure is largely used by organisations more as a marketing tool than a continuous improvement tool. This observation is in line with that made by Du and Vieira (2012) who studied corporate social responsibility as practiced by oil companies.

Figure 3 also shows that apart from one company in the electronic sector, practically no other companies are positioned at level 3 on both the social and environmental dimensions. We therefore need a framework for these companies to improve the level of disclosure in reporting their SCS initiatives and performance, thereby facilitating the enhancement of their continuous improvement scheme.

\subsection{Differences between industrial sectors}

Table IV and Figure 4 show the results of the PCA, which is used in this paper to investigate the extent to which SCS disclosure varies across different industrial sectors (research question $R Q 2$ ). First of all, Table IV shows that practically all the eight sustainability criteria are discriminating factors since there is no correlation between them, except between external relationship management and employee management (with a correlation coefficient of 0.76 ). The validity of these sustainability criteria is therefore confirmed.

The first interesting result of the PCA analysis (as can be seen in Figure 4) is that the highly polluting energy sector (on the left) is clearly distinguished as lagging behind on all the eight sustainability criteria, except on finance. Incidentally, this is a very controversial industry where unscrupulous business practices have huge social, environmental and ethical devastating consequences (Woolfson and Beck, 2005). Given the very huge investment that is required to significantly reduce pollution caused by the activities of this industry, it is not surprising that all the five oil companies studied in this paper report much more on SDS than on SCS (see Figure 2). In this regards, we note that our PCA analysis (which specifically addresses SCS disclosure) is consistent with the results of the CA (discussed in Section 4.1).

The second interesting result of the PCA analysis is that, apart from the energy (petroleum companies) sector, no obvious clusters of companies (and industrial sectors) 


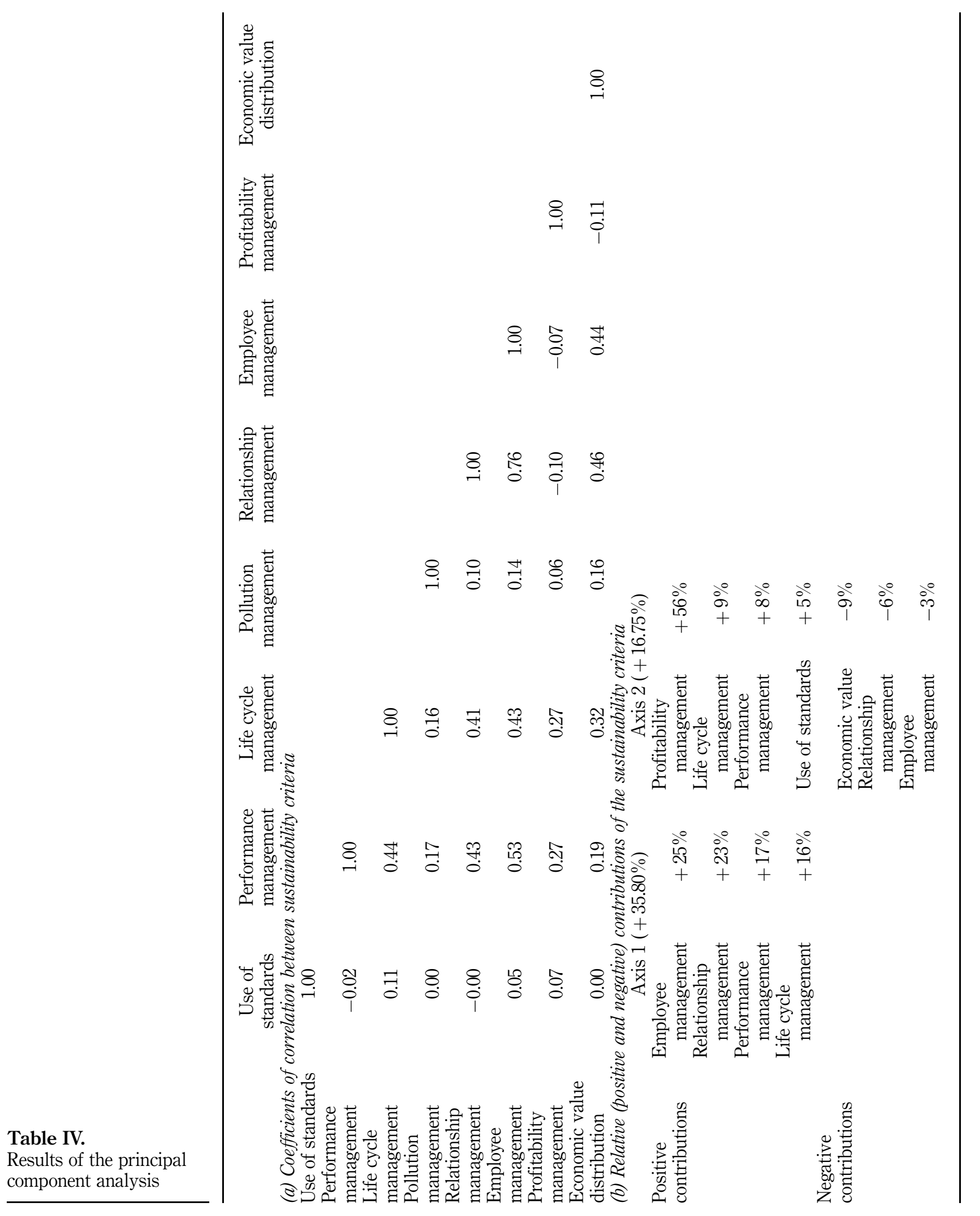




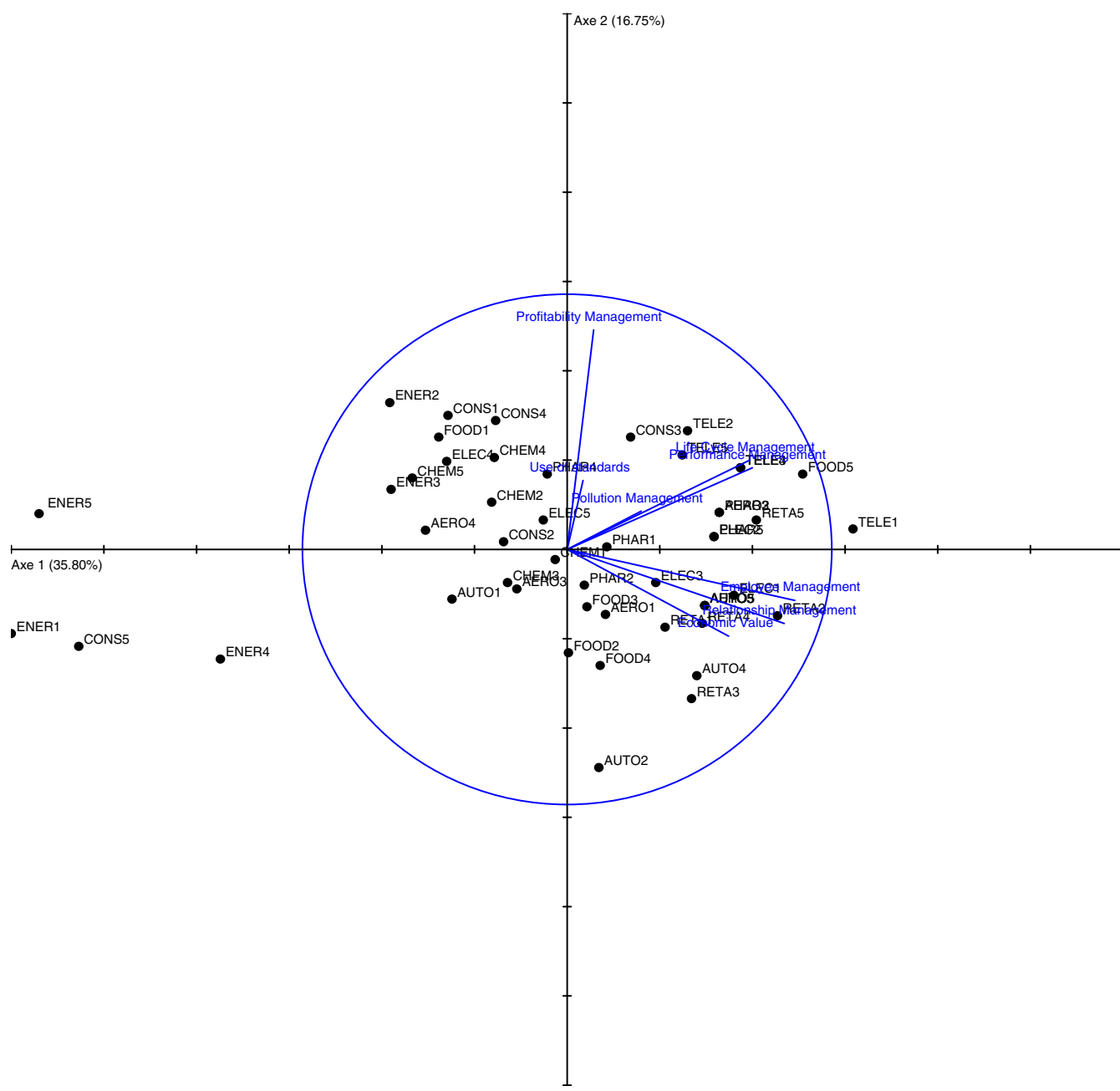

Figure 4. Graphical representation of the results of the principal component analysis

can be seen in Figure 4. As an answer to our research question $R Q 2$, we can say that the PCA analysis confirms that firms have not attained maturity in sustainability disclosure and that their behaviour (in disclosing SCS information) is not structured, neither within the same industry nor across different industries. It also confirms that there are no industry-specific indices that govern the disclosure of SCS data. This is in line with what Myers (2005) observed in the construction industry. Once again, it follows that a framework is need to enable companies to improve their disclosure maturity in a structured manner.

\subsection{Interconnection between sustainability factors}

Table IV shows the contribution of the sustainability criteria in determining the two axes of the PCA representation. It can be seen that, with a relative positive contribution of 56 per cent, profitability management (which is one of the two economic criteria) largely determines axis 2 while the environmental and social dimensions determine axis 1.

Just as in the case of differences between industrial sectors, another interesting result of the PCA analysis is that no obvious clusters of sustainability criteria can be seen in Figure 4. As an answer to our research question $R Q 3$, we can say that 
sustainability disclosure reports do not show any interconnection between sustainability criteria contrary to what is expected from the theoretical definitions of SCS that we discussed in Sections 2.1 and 2.2. This could be explained partially by the absence of accounting tools for measuring and reporting sustainability performance (Aras et al., 2010). This result clearly justifies the development and use of an integrated reporting framework such as that proposed by the IIRC. The IIRC defines integrated reporting as "a new approach to corporate reporting that demonstrates the linkages between an organisation's strategy, governance and financial performance and the social, environmental and economic context within which it operates" (Adams and Simnett, 2011).

\section{Proposed framework for improving the maturity of firms in sustainability disclosure}

In order to enable organisations to gain maturity in sustainability disclosure, we propose a framework, as shown in Table V, that is based on the continuous improvement approach and the continuous representation maturity model presented in Section 3. In the proposed framework the three levels (or steps) of maturity, which correspond to the three levels in Table II, are: define, measure and manage and improve and change. The process areas are derived from the elements of corporate and SCS listed in Table I, as well as from the eight sustainability criteria presented in Table III.

At level (or step) 1, top management has to identify key stakeholders and their needs, define objectives for SDS attributes and SCS attributes. Early, transparent and continuous stakeholder engagement will enable to improve the credibility and usefulness of the information disclosed, and subsequently lead to growth (Smith et al., 2011; Riccaboni and Leone, 2010). Hall and Matos (2010) advocate that a strong stakeholder involvement would enable to incorporate impoverished communities in sustainable supply chains, especially in the petroleum sector. At this level, effective governance also entails that top management defines the performance measurement system, as well as the internationally recognised standards that should be implemented. It is also important at this step that corporate decisions should be made in view of designing the supply chain from a lifecycle or closed-loop perspective while making sure that all the sustainable supply chain components (listed in Table I) are clearly identified and presented in a separate chapter in the sustainability report. These components include all the processes and activities, starting from the extraction of raw materials from the earth and ending with the disposal of products and packaging material (back to the earth). Some of these products may be re-used, remanufactured or recycled during their life cycle. Top management should also clearly state which of the identified stakeholders are affected by the supply chain activities of the firm, as well of its suppliers and customers.

At level (or step) 2, the disclosure report should clearly show how the corporate sustainability strategies and policies defined in step 1 are integrated and implemented across the closed-loop supply chain. Here, the organisation should also report how performance in measured and managed with respect to the three dimensions of sustainability: economic, environmental and social.

In level (or step) 3, organisations must report their improvement initiatives and show evidence of changes and progress that have been accomplished over time. Finally, at level 4, they should show evidence that the data in the report have been certified by an independent third-party organisation. The report should also clearly 


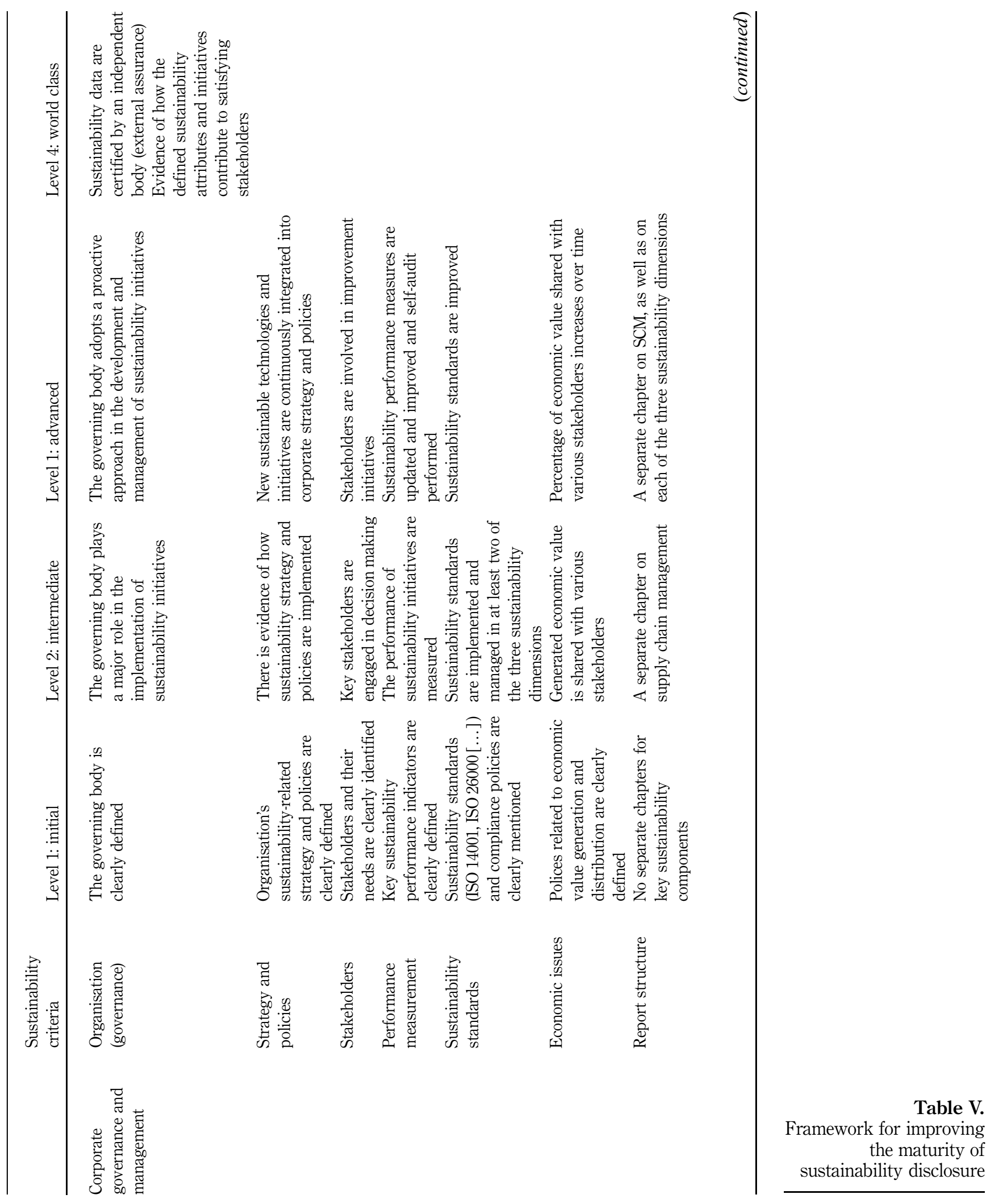




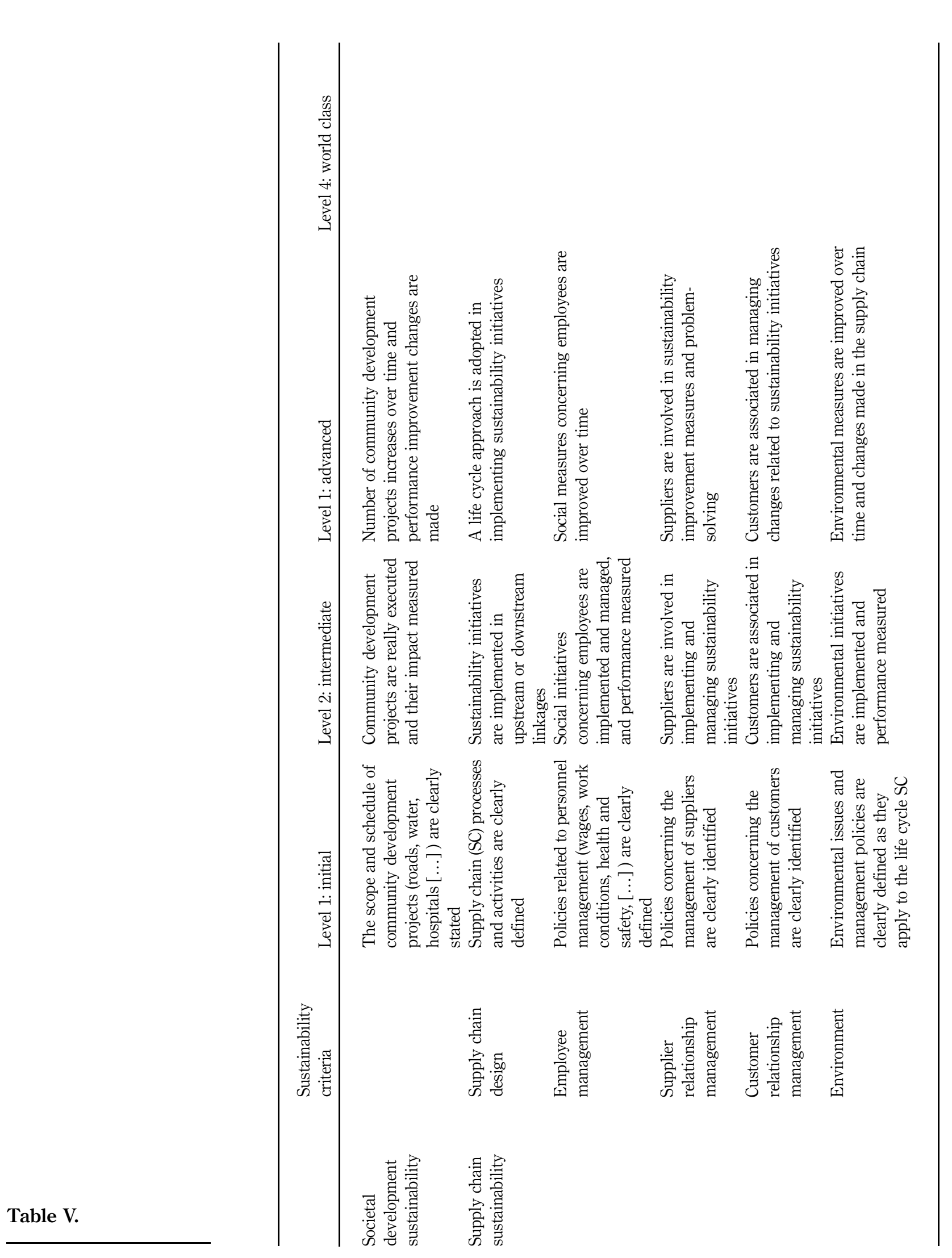


disclose how improvement on the various attributes contributes to satisfying the stakeholders.

There is no "one-size-fits all" approach in the implementation and reporting of sustainability initiatives by organisations (Hohnen and Potts, 2007). While the search for an integrated comprehensive reporting framework continues, what really matters is not what exactly is put in place by an organisation, but rather how it continuously improves its defined sustainability programmes over time. The use of the proposed framework by companies will enable to systematically analyse societal development and SCS, thereby reducing the gap between sustainable supply chain theory and empirical practice on SSCM.

\section{Conclusion}

After clarifying the definition of corporate sustainability and SSCM, this paper has empirically investigated the maturity in the disclosure of organisations' sustainability initiatives, attributes and performance as related to SDS, as well as to $\mathrm{SCS}$, using the CA approach. It further used the technique of PCA to investigate firms' disclosure maturity levels with particular emphasis on the closed-loop supply chain. It also investigated the interconnection between SCS criteria. The results show that: first, there is little or no correlation between the sustainability criteria; second, $\mathrm{B} 2 \mathrm{C}$ companies tend to disclose their SCS policies and initiatives more than $\mathrm{B} 2 \mathrm{~B}$ companies; third, the results also show that the highly polluting energy sector is the least advanced in implementing and disclosing SCS initiatives; fourth, the overall level of disclosure on SCS is low compared to theoretical expectations. Given these observations, we have proposed a framework that will enable companies to improve the disclosure of their corporate sustainability initiatives in general and their SCS initiatives in particular.

The results of this study would enable to incite different stakeholders (especially customers, shareholders, investors, NGOs and the society) to searching for a logical progression of key information when reading organisations' sustainability reports. They should start by checking whether or not top management clearly states strategies and policies, as well as performance measures that aim to satisfy their needs and requirements. They should move on to check how sustainability initiatives are really measured and managed in line with the corporate strategies and policies. Finally, they should check what improvement processes and initiatives are implemented and whether the data in the report are certified by an external body. This logical and intelligent way of reading sustainability reports would lead them to focusing on important issues, thereby obliging organisation to improve the quality and reliability of the disclosed information. Researchers could also use the results of this study to better structure their work on disclosure.

The main difficulty that we encountered is analysing reports that are presented based on very different formats, level of details and styles. This probably made our CA and PCA to lack robustness. Though some important exploratory findings are presented in this paper, further research needs to be done in order to not only improve the validity of our findings by using a carefully selected list of companies that use exactly the same reporting framework, but also to perform a more detailed cluster analysis by designing a more robust scoring system. A longitudinal investigation needs also to be done in order to show how SCS disclosure evolves over time, as well as improvements made by the same companies in their disclosure process. 


\section{References}

ACCA (2011), "Disclosures on supply chain sustainability", ACCA report, Net Balance Foundation and Sustainable Investment Research Institute, London, pp. 1-36.

Accenture (2012), “CDP supply chain report 2012”, Report written for CDP, London, pp. 1-20.

Adams, S. and Simnett, R. (2011), "Integrated reporting: an opportunity for Australia's notfor-profit sector", Australian Accounting Review, Vol. 58 No. 21, pp. 292-301.

Aiking, H. and De Boer, J. (2004), "Food sustainability: diverging interpretations", British Food Journal, Vol. 106 No. 5, pp. 359-365.

Alexopoulos, I., Kounetas, K. and Tzelepis, D. (2012), "Environmental performance and technical efficiency, is there a link? The case of Greek listed firms", International Journal of Productivity and Performance Management, Vol. 61 No. 1, pp. 6-23.

Aras, G. and Crowther, D. (2008), "Governance and sustainability: an investigation into the relationship between corporate governance and corporate sustainability", Management Decision, Vol. 46 No. 3, pp. 433-448.

Aras, G., Aybars, A. and Kutlu, O. (2010), "Managing corporate performance: investigating the relationship between corporate social responsibility and financial performance in emerging markets", International Journal of Productivity and Performance Management, Vol. 59 No. 3, pp. 229-254.

Arimura, T.H., Darnall, N. and Katayama, H. (2009), "Is ISO 14001 a gateway to more advanced voluntary action? A case for green supply chain management", discussion paper, RFF, Washington, DC, pp. 09-05.

Asif, M., Searcy, C., Garvare, R. and Ahmad, N. (2011), "Including sustainability in business excellence models", Total Quality Management, Vol. 22 No. 7, pp. 773-786.

Bai, C., Sarkis, J., Wei, X. and Koh, L. (2012), "Evaluating ecological sustainable performance measures for supply chain management", Supply Chain Management: An International Journal, Vol. 17 No. 1, pp. 78-92.

Ballou, B., Casey, R.J., Grenier, J.H. and Heitger, D.L. (2012), "Exploring the strategic integration of sustainability initiatives: opportunities for accounting research", Accounting Horizons, Vol. 26 No. 2, pp. 265-288.

Bask, A. and Kuula, M. (2011), "Measuring supply chain level environmental sustainability case Nokia", International Journal of Business Insights and Transformation, Vol. 3 No. 3, pp. 16-24.

Baumgartner, R.J. and Ebner, D. (2010), "Corporate sustainability strategies: sustainability profiles and maturity levels", Sustainable Development, Vol. 18 No. 2, pp. 76-89.

Beamon, B.M. (1999), "Designing the green supply chain”, Logistics Information Management, Vol. 12 No. 4, pp. 332-342.

Beamon, B.M. (2005), "Environmental and sustainability ethics in supply chain management", Science and Engineering Ethics, Vol. 11 No. 2, pp. 221-234.

Bebbington, J., Larrinaga-González, C. and Moneva, J.M. (2008), “Corporate social responsibility and reputation risk management", Accounting Auditing and Accountability Journal, Vol. 21 No. 3, pp. 337-362.

Beske, P. (2012), "Dynamic capabilities and sustainable supply chain management", International Journal of Physical Distribution \& Logistics Management, Vol. 42 No. 4, pp. 372-387.

Björklund, M. and Forslund, H. (2013), "The purpose and focus of environmental performance measurement systems in logistics", International Journal of Productivity and Performance Management, Vol. 62 No. 3, pp. 230-249.

Brundtland, G.H. (Ed.) (1987), Our Common Future: The World Commission on Environment and Development, Oxford University Press, Oxford. 
Bryman, A.E. and Hardy, M.A. (2003), Handbook of Data Analysis, Sage publications, London. BSR (2007), "Perspectives of information management in supply chains", Business for Social Responsibility Report, New York, NY, pp. 1-12.

BSR (2010), "Supply chain sustainability: a practical guide for continuous improvement", UN Global Compact, New York, NY, pp. 1-68.

Carter, C.R. and Rogers, D.S. (2008), "A framework of sustainable supply chain management: moving toward new theory", International Journal of Physical Distribution \& Logistics Management, Vol. 38 No. 5, pp. 360-387.

Castka, P. and Balzarova, M.A. (2008), "ISO 26000 and supply chains: on the diffusion of the social responsibility standard", International Journal of Production Economics, Vol. 111 No. 2, pp. 274-286.

Cetinkaya, B. (2011), "Developing a sustainable supply chain strategy", in Cetinkaya, B., Cuthbertson, R., Ewer, G., Wissing, T., Piotrowicz, W. and Tyssen, C. (Eds), Sustainable Supply Chain Management, Chapter 2, Springer, Berlin, pp. 17-55

Christopher, M. (1992), Logistics and Supply Chain Management, Pitman Publishing, London.

Cormier, D., Gordon, I.M. and Magnan, M. (2004), "Corporate environmental disclosure: contrasting management's perception with reality", Journal of Business Ethics, Vol. 49 No. 2, pp. 143-165.

Courville, S. (2003), "Use of indicators to compare supply chains in the coffee industry", Management International, Autumn, No. 43, pp. 93-105.

Curry, E., Guyon, B., Sheridan, C. and Donnellan, B. (2012), "Developing a sustainable IT capability: lessons from Intel's journey”, MIS Quarterly Executive, Vol. 11 No. 2, pp. 61-72.

Darnall, N., Jolley, G.J. and Handfield, R. (2008), "Environmental management systems and green supply chain management: complements for sustainability?", Business Strategy and the Environment, Vol. 17 No. 1, pp. 30-45.

De Man, R. and Burns, T.R. (2006), "Sustainability: supply chains, partner linkages, and new forms of self-regulation", Human Systems Management, Vol. 25 No. 1, pp. 1-12.

Du, S. and Vieira, E.T. Jr (2012), "Striving for legitimacy through corporate social responsibility: insights from oil companies", Journal of Business Ethics, Vol. 110 No. 4, pp. 413-427.

Dyllick, T. and Hockerts, K. (2002), "Beyond the business case for corporate sustainability", Business Strategy and the Environment, Vol. 11 No. 2, pp. 130-141.

EFQM (2013), "The EFQM excellence model”, available at: www.efqm.org/ (accessed 16 April 2013).

Elkington, J. (1994), “Towards the sustainable corporation: Win-Win-Win business strategies for sustainable development”, California Management Review, Vol. 36 No. 2, pp. 90-100.

Elkington, J. (1997), Cannibals with Forks: The Triple Bottom Line of 21st Century Business, Capstone, New Society, Oxford.

Facanha, C. and Horvath, A. (2008), "Environmental assessment of logistics outsourcing", Journal of Management in Engineering, January, ASCE, Vol. 21 No. 1, pp. 27-37.

Field, J.M. and Sroufe, R.P. (2007), "The use of recycled materials in manufacturing: implications for supply chain management and operations strategy", International Journal of Production Research, Vol. 45 Nos 18-19, pp. 4439-4463.

Filho, W.L. (2000), "Dealing with misconceptions on the concept of sustainability", International Journal of Sustainability in Higher Education, Vol. 1 No. 1, pp. 9-19.

Freeman, R.E. (1984), Strategic Management: A Stakeholder Approach, Prentice-Hall, Englewood Cliffs, NJ.

Gao, S.S. and Zhang, J.J. (2006), "Stakeholder engagement, social auditing and corporate sustainability”, Business Process Management Journal, Vol. 12 No. 6, pp. 722-740.

Geldermann, J., Treitz, M. and Rentz, O. (2007), "Towards sustainable production networks", International Journal of Production Research, Vol. 45 Nos 18-19, pp. 4207-4224. 
Gopal, P.R.C. and Thakkar, J. (2012), "A review on supply chain performance measures and metrics: 2000-2011", International Journal of Productivity and Performance Management, Vol. 61 No. 5, pp. 518-547.

Gori, E., Romolini, A. and Fissi, J. (2012), "Social accountability in Italian listed companies: communication or voluntary disclosure?”, China-USA Business Review, Vol. 11 No. 6, pp. 779-795.

GRI (2010), "Global action network for transparency in the supply chain (GANTSCh) program", available at: www.globalreporting.org/resourcelibrary/Global-Action-Network-forTransparency-in-the-Supply-Chain-Program-Overview.pdf (accessed 8 April 2013).

Hall, J. and Matos, S. (2010), "Incorporating impoverished communities in sustainable supply chains", International Journal of Physical Distribution and Logistics Management, Vol. 40 Nos 1/2, pp. 124-147.

Handfield, R., Stroufe, R. and Walton, S. (2005), "Integrating environmental management and supply chain strategies", Business Strategy and the Environment, Vol. 14 No. 1, pp. 1-19.

Hemming, C., Pugh, S., Williams, G. and Blackburn, D. (2004), "Strategies for sustainable development: use of a benchmarking tool to understand relative strengths and weaknesses and identify best practice", Corporate Social Responsibility and Environmental Management, Vol. 11 No. 2, pp. 103-113.

Henriques, I. and Sadorsky, P. (1999), "The relationship between environmental commitment and managerial perceptions of stakeholder importance", Academy of Management Journal, Vol. 42 No. 1, pp. 87-99.

Hervani, A.A. and Helms, M.M. (2005), "Performance measurement for green supply chain management”, Benchmarking: An International Journal, Vol. 12 No. 4, pp. 330-353.

Hodson, R. (1999), Analyzing Documentary Accounts, Thousand Oaks, Sage, GA.

Holsti, O.R. (1969), Content Analysis for the Social Sciences and Humanities, Reading, AddisonWesley, MA.

Hohnen, P. and Potts, J. (2007), “Corporate social responsibility: an implementation guide for business", International Institute for Sustainable Development, Manitoba.

Hubbard, G. (2011), "The quality of the sustainability reports of large international companies: an analysis", International Journal of Management, Vol. 28 Nos 3 Part 2, pp. 824-848.

Hys, K. and Hawrysz, L. (2012), "Corporate social responsibility reporting”, China-USA Business Review, Vol. 11 No. 11, pp. 1515-1524.

Jarvenpaa, S.L. (1991), "Panning for gold in information system research: 'Second hand' data", in Nissen, H.E., Klein, H.K. and Hirschheim, R. (Eds), Information Systems Research: Contemporary Approaches and Emergent Traditions, Elsevier Science, Amsterdam, pp. 63-80.

Jose, A. and Lee, S.-M. (2007), "Environmental reporting of global corporations: a content analysis based on website disclosure", Journal of Business Ethics, Vol. 72 No. 4, pp. 307-321.

Kang, Y., Ryu, M.-H. and Kim, S. (2010), "Exploring sustainability management for telecommunication services: a case study of two companies", Journal of World Business, Vol. 45 No. 4, pp. 415-421.

Kiewiet, D.J. and Vos, J.F.J. (2007), "Organisational sustainability: a case for formulating a Taylormade definition", Journal of Environmental Assessment Policy and Management, Vol. 9 No. 1, pp. 1-18.

Kleindorfer, P.R., Singhal, K. and van Wassenhove, L.N. (2005), "Sustainable operations management”, Production and Operations Management, Vol. 14 No. 4, pp. 482-492.

KPMG (2008), KPMG International Survey of Corporate Responsibility Reporting 2008, University of Amsterdam, Amsterdam.

Krikke, H., Le Blanc, I. and van de Velde, S. (2004), "Product modularity and the design of closedloop supply chains”, California Management Review, Vol. 46 No. 2, pp. 23-39. 
Krippendorff, K. (1980), Content Analysis: An Introduction to its Methodology, Sage, Beverly Hills, CA.

Kwik, S.S., Nagalingam, S.V. and Amer, Y. (2011), "Sustainable supply chain for collaborative manufacturing", Journal of Manufacturing Technology Management, Vol. 22 No. 8, pp. 984-1001.

Lieberman, M.B. and Balasubramanian, N. (2005), "Measuring value creation and its distribution among stakeholders of the firm", Academy of Management Annual Meeting 2005, Hawaii.

Linton, J.D., Klessen, R. and Jayaraman, V. (2007), "Sustainable supply chains: an introduction", Journal of Operations Management, Vol. 25 No. 6, pp. 1075-1082.

Lukman, T., Hackney, R., Popovič, A., Jaklič, J. and Irani, Z. (2011), "Business intelligence maturity: the economic transitional context within Slovenia", Information Systems Management, Vol. 28 No. 3, pp. 211-222.

Mani, M., Lyons, K. and Sriram, R. (2010), "Developing a sustainability manufacturing maturity model", Proceedings from the IMS Summer School on Sustainable Manufacturing, pp. 311-321.

Meng, X., Sun, M. and Jones, R. (2011), "Maturity model for supply chain relationships in construction", Journal of Management in Engineering, Vol. 27 No. 2, pp. 97-105.

Michelon, G. (2011), "Sustainability disclosure and reputation: a comparative study", Corporate Reputation Review, Vol. 14 No. 2, pp. 79-96.

Myers, D. (2005), "A review of construction companies' attitudes to sustainability", Construction Management and Economics, Vol. 23 No. 8, pp. 781-785.

Nidumolu, R., Prahalad, C.K. and Rangaswami, M.R. (2009), "Why sustainability is now the key driver of innovation”, Harvard Business Review, September, pp. 57-64.

Peukert, J. and Sahr, K. (2010), "Sustainability in the chemical and pharmaceutical industry: results of a benchmark analysis", Journal of Business Chemistry, Vol. 7 No. 2, pp. 97-106.

Pojasek, R.B. (2012), "Understanding sustainability: an organisational perspective", Environmental Quality Management, Vol. 21 No. 3, pp. 93-100.

Presley, A., Meade, L. and Sarkis, J. (2007), “A strategic sustainability justification methodology for organisational decisions: a reverse logistics illustration", International Journal of Production Research, Vol. 45 Nos 18-19, pp. 4595-4620.

Pullen, W. (2007), “A public sector HPT maturity model”, Performance Improvement, Vol. 46 No. 4, pp. 9-15.

Rahimifard, S. and Clegg, A.J. (2007), "Aspects of sustainable design and manufacture", International Journal of Production Research, Vol. 45 Nos 18-19, pp. 4013-4019.

Rao, P. and Holt, D. (2005), "Do green supply chains lead to competiveness and economic performance?", International Journal of Operations \& Production Management, Vol. 25 No. 9, pp. 898-916.

Riccaboni, A. and Leone, E.L. (2010), "Implementing strategies through management control systems: the case of sustainability", International Journal of Productivity and Performance Management, Vol. 59 No. 2, pp. 130-144.

Robins, F. (2006), "The challenge of TBL: a responsibility to whom?", Business Soc. Review, Vol. 111 No. 1, pp. 1-14.

Rocha, M., Searcy, C. and Karapetrovic, S. (2007), "Integrating sustainable development into existing management systems", Total Quality Management, Vol. 18 Nos 1-2, pp. 83-92.

Savage, G.T., Nix, T.W., Whitehead, C.J. and Blair, J.D. (1991), "Strategies for assessing and managing organisational stakeholders", Academy of Management Executive, Vol. 5 No. 2, pp. 61-75. 
Schaltegger, S. and Wagner, M. (2006), "Integrative management of sustainability performance, measurement and reporting", International Journal of Accounting, Auditing and Performance Evaluation, Vol. 3 No. 1, pp. 1-19.

Seuring, S. (2008), "Assessing the rigor of case study research in supply chain management", Supply Chain Management, Vol. 13 No. 2, pp. 128-137.

Seuring, S. and Muller, M. (2008), "From a literature review to a conceptual framework for sustainable supply chain management", Journal of Cleaner Production, Vol. 16 No. 15, pp. 1699-1710.

Sherman, W.R. and DiGuilio, L. (2010), "The second round of G3 reports: is triple bottom line reporting becoming more comparable?", Journal of Business and Economics Research, Vol. 8 No. 9, pp. 59-77.

Shrivastava, P. (1995), "The role of corporations in achieving ecological sustainability", Academy of Management Review, Vol. 20 No. 4, pp. 936-960.

Simpson, D.F. and Power, D.J. (2005), "Use the supply relationship to develop lean and green suppliers", Supply Chain Management: An International Journal, Vol. 10 No. 1, pp. 60-68.

Smith, N.C., Ansett, S. and Erez, A. (2011), "What is at stake? Stakeholder engagement strategy as the key to sustainable growth", working paper, INSEAD Faculty and Research, 2011/25/ AL/ISIC, Fontainebleau.

Snir, E.M. (2001), "Liability as a catalyst for product stewardship", Production and Operations Management, Vol. 10 No. 2, pp. 190-206.

Srivastava, S.K. (2008), "Network design for reverse logistics", The International Journal of Management Science, Omega, Vol. 36 No. 4, pp. 535-548.

Türetken, O. and Demirörs, O. (2004), "People capability maturity and human resource management systems: do they benefit each other?", Human Systems Management, Vol. 23 No. 3, pp. 179-190.

UN Global Compact (2013), “Tools and resources”, available at: www.unglobalcompact.org/ (accessed 8 April 2013).

Vachon, S. (2007), "Green supply chain practices and the selection of environmental technologies", International Journal of Production Research, Vol. 45 Nos 18-19, pp. 4357-4379.

Vachon, S. and Klassen, R. (2006), "Extending green practices across the supply chain", International Journal of Operations \& Production Management, Vol. 26 No. 7, pp. 795-821.

Vermeulen, W.J.V. (2008), "Sustainable global product chains: actors, systems and mechanisms at three levels", paper for the 14th Annual International Sustainable Development Research Conference, India Habitat Center, New Delhi, 21-23 September.

Watson, A., Shrives, P. and Marston, C. (2002), "Voluntary disclosure of accounting ratios in the UK”, British Accounting Review, Vol. 34 No. 2, pp. 289-231.

Wiedmann, T. and Lenzen, M. (2008), "Unravelling the impacts of supply chains - a new triplebottom-line accounting approach and software tool", in Schaltegger, S., Bennett, M., Burritt, R.L. and Jasch, C. (Eds), Environmental Management Accounting For Cleaner Production, Chapter 4, Springer, Dordrecht, NL, pp. 65-90.

Wilson, M. (2003), “Corporate sustainability: what is it and where does it come from?", Ivey Business Journal, No. March/April, Vol. 67 No. 4, pp. 1-5.

Wirtenberg, J., Harmon, J. and Fairfield, K.D. (2007), "HR's role in building a sustainable enterprise: insights from some of the world's best companies", Human Resource Planning, Vol. 30 No. 1, pp. 10-20. 
Woolfson, C. and Beck, M. (2005), Corporate Social Responsibility Failures in the Oil Industry, Baywood Publishing, New York, in Du S. and Vieira E.T. Jr (2012), "Striving for legitimacy through corporate social responsibility: insights from oil companies", Journal of Business Ethics, Vol. 110, pp. 413-427.

Zhu, Q., Sarkis, J. and Geng, Y. (2005), "Green supply chain management in China: pressures, practices and performance", International Journal of Operations \& Production Management, Vol. 25 No. 5, pp. 449-468.

\section{Corresponding author}

Professor Uche Okongwu can be contacted at: u.okongwu@esc-toulouse.fr 